\title{
Integrated Geochemical and Multivariate Statistical Examination of Source Rocks in the Sokoto and Anambra Basins, Nigeria: Implications for Hydrocarbon Prospectivity
}

\author{
Lukman Musa Adamu ${ }^{1, ~ *, ~ N u h u ~ G e o r g e ~ O b a j e ~}{ }^{2,3}$, Okafor Pudentiana Ngozi ${ }^{4}$, \\ Umar Mohammed Umar ${ }^{3}$ \\ ${ }^{1}$ Department of Earth Sciences, Kogi State University, Anyigba, Nigeria \\ ${ }^{2}$ Nigerian National Petroleum Corporation Chair in Basinal Studies, Ibrahim Badamasi Babangida University, Lapai, Nigeria \\ ${ }^{3}$ Department of Geology, Ibrahim Badamasi Babangida University, Lapai, Nigeria \\ ${ }^{4}$ Department of Geology, University of Nigeria, Nsukka, Nigeria
}

Email address:

lukman10musa@yahoo.com (L. M. Adamu), adamulm@ksu.edu.ng (L. M. Adamu)

${ }^{*}$ Corresponding author

\section{To cite this article:}

Lukman Musa Adamu, Nuhu George Obaje, Okafor Pudentiana Ngozi, Umar Mohammed Umar. Integrated Geochemical and Multivariate Statistical Examination of Source Rocks in the Sokoto and Anambra Basins, Nigeria: Implications for Hydrocarbon Prospectivity. Petroleum Science and Engineering. Vol. 4, No. 2, 2020, pp. 39-50. doi: 10.11648/j.pse.20200402.11

Received: May 21, 2020; Accepted: June 4, 2020; Published: June 15, 2020

\begin{abstract}
The LECO and Rock-Eval pyrolysis for 7 shale and 3 coal samples, as well as, multivariate statistical analysis have been used to probe source rock characteristics, correlation between the assessed parameters (S1, S2, S3, HI, S1 + S2, OI, PI, TOC) and the impact of changes in the Tmax on the assessed parameters in the Sokoto Basin and Anambra Basin of northwestern and southeastern Nigeria respectively. The geochemical results show that $93 \%$ of the samples have TOC values greater than the minimum limit value $(0.5 \mathrm{wt} \%)$ required to induce hydrocarbon generation from source rocks. Meanwhile, the Dukamaje and Taloka shales are found to be fair to good source rock for oil generation with slightly higher thermal maturation. The source rocks are generally immature through sub-mature to marginal mature with respect to the oil and gas window, while the potential source rocks from the Anambra Basin are generally sub-mature grading to mature within the oil window. The analyzed data were approached statistically to find some relations such as factors, and clusters concerning the examination of the source rocks. These factors were categorized into type of organic matter and organic richness, thermal maturity and hydrocarbon potency. In addendum, cluster analysis separated the source rocks in the study area into two groups. The source rocks characterized by HI $>240(\mathrm{mg} / \mathrm{g})$, TOC from 58.89 to $66.43 \mathrm{wt} \%$, S1 from 2.01 to $2.54(\mathrm{mg} / \mathrm{g})$ and S2 from 148.94 to $162.52(\mathrm{mg} / \mathrm{g})$ indicating good to excellent source rocks with kerogen of type II and type III and are capable of generating oil and gas. Followed by the Source rocks characterized by HI $<240(\mathrm{mg} / \mathrm{g})$, TOC from 0.94 to $6.68 \mathrm{wt} \%$, S1 from 0.14 to 0.72 $(\mathrm{mg} / \mathrm{g})$ and S2 from 0.14 to $3.36(\mathrm{mg} / \mathrm{g})$ indicating poor to good source rocks with kerogen of type III and are capable of generating gas. Howeverr, Pearson's correlation coefficient and linear regression analysis shows a significant positive correlation between TOC and S1, S2 and HI and no correlation between TOC and Tmax, highly negative correlation between TOC and OI and no correlation between Tmax and HI.
\end{abstract}

Keywords: Anambra Basin, LECO, Multivariate Statistical, Rock-Eval Pyrolysis, Sokoto Basin

\section{Introduction}

Presently data set are being gathered through surveys to enable extensive appraisal of the oil and gas possibilities in the frontier basins of Nigeria by the Nigerian government through the Nigerian National Petroleum Corporation and other investors. These basins include the Anambra Basin, Benue Trough, Bida Basin, Chad Basin (Nigerian sector), Dahomey Basin and Sokoto Basins (Figure 1). The oil and gas potency in the basins will depend on the fortune of the elements that make up the petroleum system. The elements 
include organically rich, mature source rocks and their volumes, porous and permeable reservoir rocks and seal lithologies, effective generation, expulsion and migration into reservoirs, availability of trapping mechanisms and timing of generation, expulsion and migration in relation to other events. At the centre of the petroleum system is the availability of organically rich, mature source rocks. Source rocks for petroleum generation are usually shales, carbonates and coals.

The northwestern Nigeria Sokoto Basin occupies the geographical Sokoto State, and parts of Zamfara and Kebbi State, covers about $20 \%$ of the northeastern region of Nigeria. It is considered as one of the promising basins in the country with good potential oil and gas deposits with area of about $60,000 \mathrm{~km}^{2}$ and is also the least studied basin in Nigeria [1-3]. Potential hydrocarbon source rocks exposed in outcrops and stratigraphic sections in the Sokoto Basin, and a preliminary assessment of the hydrocarbon prospectivity using the organic geochemical tools (LECO and Rock-Eval pyrolysis analysis) had earlier been studied [1, 2]. They identified the source to be mainly the carbonaceous Dukamaje and/or Taloka shales. These methods are used in determining the thermal maturation of kerogen. Behar et al. [4] defined the thermal parameters based on which maximum temperature (Tmax) can be used to model the proportions of the oil window. Thermal maturity of sediments can be ascertained with production of graph that plots Tmax values versus HI. In this study, we used both geochemical and statistical analyses for evaluating the source rocks in the northwestern Sokoto Basin.

In this study, both geochemical and statistical analyses were used for evaluating the source rocks and discriminate the maturity and hydrocarbon potentialities of the northwestern Lower and Middle Maastrichtian source rocks in the northwestern Sokoto Basin and the CampanianMaastrichtian source rocks in the Anambra Basin. This work has studied the geochemical properties of organic material, thermal maturation and affluence of hydrocarbon in order to square up the petroleum potency of the source rocks. The intention of this study is to set up indices for a unified appraisal of organic material for petroleum potency evaluation and pivot on multivariate statistical analysis and cross-plots of TOC, and parameters of Rock-Eval pyrolysis. With speculative and analytical examination, we anticipate to uncover that the utility of seven (7) parameters (S1, S2, S3, $\mathrm{S} 1+\mathrm{S} 2, \mathrm{HI}, \mathrm{OI}, \mathrm{PI}, \mathrm{TOC})$ increase as the thermal maturity of organic materials increase during the initial stage of thermal maturation. In addendum, this study is to style the affinities between organic material and thermal maturity.

\section{Geological / Stratigraphy Setting}

The discussion on the geological setting focuses on the Sokoto Basin being the south-eastern portion of the larger Iullemmeden Basin. The Iullemmeden Basin covers northwestern Nigeria, most parts of Niger Republic, Benin Republic, Mali, Algeria and Libya. This geological setting hosts the appraised carbonaceous shale deposits (Figures 1, 2, 3, 4).

\subsection{The Northwestern Sokoto Basin}

Kogbe $[5,6]$ carried out a work on geology of the southeastern (Sokoto) sector of the Iullemmeden Basin and produced a detailed geological map of the Sokoto Basin. Obaje [7] worked on the Foraminiferal biostratigraphy and paleoenvironment of the Sokoto Basin of NW Nigeria. Obaje, [8] in his book titled 'The Geology and Mineral Resources of Nigeria' give a detailed stratigraphic description of the formations within the basin.

The main lithologies of the northwestern Sokoto Basin range in chronology from Pre-Maastrichtian to Eocene [6-8, 3] (Figure 4). The stratigraphic rock units comprise continental and marine sediments (Figure 4). The PreMaastrichtian part is represented by siliciclastics GundumiIllo Formation. This formation is wholly grits and clays that constitute the Pre-Maastrichtian 'Continental Intercalaire' which rest unconformably on the Pre Cambrian basement rocks of the northwestern Nigeria (Figure 4). The PreMaastrichtian Gundumi-Illo Formation also unconformably underlies the Rima Group which comprise of the Taloka, Dukamaje and Wurno Formations. The Lower Maastrichtian Taloka Formation is composed mainly mudstone and friable sandstones and shales with coal seems, and is overlain conformably by Middle Maastrichtian marine Dukamaje Formation (Figure 4) composed mainly of fossiliferous, calcareous and shales. The Dokamaje Formation is overlain conformably by Upper Maastrichtian Wurno Formation. The continental sandstone of the Wurno Formation are overlain unconformably by Paleocene units of Sokoto Group (Figure 4). The Paleocene units comprise the Dange, Kalambaina and Gamba Formations. The Dange Formation (Lower Paleocene) composed of mainly marine shales. Kalambaina Formation represents a calcareous sequence. Gamba Formation consist of mainly marine shales, and it is uncoformably overlain by Eocene continental Gwandu Formation (Figure 4) which forms the Eocene Continental Terminal.

\subsection{The Anambra Basin}

The Anambra Basin is sometimes seen as an integral unit of the Lower Benue Trough (Figure 1 and Figure 3). During the Santonian, upheavals (epeirogenic) movements, these sediments experience flexure and uplifted into the Abakaliki-Benue Anticlinorium [9] with synchronous subsidence of the Anambra Basin and the Afikpo sub- basins to the northwest and southeast of the folded belt respectively [9-11]. The Abakaliki Anticlinorium later served as a sediment disbandment centre from which sediments were shifted into the Anambra Basin and Afikpo Syncline. The Cameroon basement complex, Oban Masif and southwestern Nigeria basement craton also served as sources for the sediments of the Anambra Basin [12]. Postdeformational sedimentation in the Lower Benue Trough, therefore, constitutes the Anambra Basin.

After the development of the Anambra Basin following the 
Santonian epeirogeny, the Campanian-early Maastrichtian transgression deposited the Nkporo Group (i.e the Enugu Formation, Owelli Sandstone, Nkporo Shale, Afikpo Sandstone, Otobi Sandstone and Lafia Sandstone) as the basal unit of the basin, unconformably overlying the Awgu Formation. This was followed by the Maastrichtian regressive event during which the coal measures (i.e. the Mamu, Ajali and Nsukka Formations) were deposited. The Enugu and the Nkporo Shales represent the pro-delta fossiliferous facies of the Late Campano-Maastrichtian depositional cycle [8]. Deposition of the sediments of the Nkporo/Enugu Formations reflects a funnel-shaped shallow marine setting that graded into channeled low-energy marshes. The coal-bearing Mamu Formation and the Ajali Sandstone accumulated during this epoch of overall regression of the Nkporo cycle. The Mamu Formation occurs as a narrow strip trending north-south from the Calabar Flank, swinging west around the Ankpa plateau and terminating at Idah near the River Niger $[8,13,14]$. The Ajali Sandstone marks the height of the regression at a time when the coastline was still concave. The converging littoral drift cells governed the sedimentation and are reflected in the tidal sand waves which are characteristic for the Ajali Sandstone $[15,13,16,11,17,18]$.

\section{Samples and Methods}

Ten selected shale and coal rock ditch and field samples from Dukamaje and Taloka Formations of the northwestern Sokoto Basin and Enugu and Mamu Formations of the Anambra Basin (Table 1) were analyzed for total organic carbon, and Rock-Eval pyrolysis. The LECO TOC content and Rock-Eval pyrolysis analyses were made partly in the laboratories of Geo-data GmbH Garbsen and partly at BGR Hannover, both in Germany through the instrumentality of the $2^{\text {nd }}$ author (NGO). The Analyses were performed on 70 $\mathrm{mg}$ to $100 \mathrm{mg}$ crushed whole rock samples, heated to $600^{\circ} \mathrm{C}$ in a helium atmosphere, using a LECO and Rock-Eval 6 unit.

Multivariate statistical analysis was applied to evaluate the source rock potentiality and clarify the relationship between petroleum potential and maturity. The results obtained for studied samples were statistically analyzed using cluster analysis (hierarchical cluster analysis), Factor analysis, Kindependence sample T-tests, linear regression and Pearson's correlation by SPSS 15.0 [19].

\subsection{Cluster Analysis}

Cluster analysis is based on a matrix measuring the differences between each parameter of each sample. Two basic types of cluster analyses are known: K-Means and hierarchical types. For K-means analysis, it is necessary to define the number of groups into which the samples/parameters are to be classified, while hierarchical cluster analysis enables the grouping of the samples or parameters without any previous classification [20]. These differences are squared. By adding the individual matrices, a summed matrix is obtained. In the case when the values of the parameters are essentially different, they should preliminarily be standardized, in order that in the final matrix each parameter becomes an equal share. Based on the final matrix, a dendrogram is constructed, which involves all samples or parameters being classified into groups on the basis of all data taken into consideration [21].

\subsection{Factor Analysis}

According to [22], the statistical method used for combining a large number of data into a considerably smaller number of factors, representing groups of initially mutually linearly dependent parameters containing the same amount of information as their constituent parameters is known as Factor analysis. The values of the coefficients preceding the parameters, marked as loadings, define the significance of a particular parameter in the characterization of an analyzed group of samples. The significance of a particular factor is defined by its characteristic value and percent of variance $[23,24]$. In order to determine the relationship between the parameters for the sake of classification of the samples, an interdependence diagram of two factors may be constructed [25]. In the case when the parameters are defining factors reflecting certain types of reaction characteristic for the investigated group of samples, the course of these processes and their mutual agreement can be proven by constructing corresponding correlation diagrams of these factors [25].

\subsection{Pearson's Correlation Coefficient and Linear Regression}

El-Nady and Lotfy, [20] described Pearson's correlation coefficient is as a statistical measure of the strength of a linear relationship between paired data. The correlation coefficient can range from -1 to +1 , with -1 indicating a perfect negative correlation, +1 indicating a perfect positive correlation, and 0 indicating no correlation at all. (A variable correlated with it will always have a correlation coefficient of 1). Linear regression is the next step after correlation. It is used when we want to predict the value of a variable based on the value of another variable. The variable we want to predict is called the dependent or outcome variable. The variable we are using to predict the other variable's value is called the independent or the predictor variable [20].

\section{Results and Discussion}

\subsection{Geochemical Methods}

In order to examine the organic carbon content and source rock maturity different factors including quality and quantity of organic matter, generating potentialities, type of organic matter and thermal maturation were considered.

\subsubsection{Quality and Quantity of Organic Matter}

The organic carbon richness of the rock samples (TOC \%), is important in the examination of sediments as a source for petroleum. Tissot and Welte [26-34] presented a scale for the 
assessment of source rocks potency, based on the TOC $\%$ and Rock-Eval pyrolysis data, such as S1 and S2. The procured data set in Table 1 show that the total organic carbon content values for the northwestern Sokoto Basin source rocks are between 0.94 and $7.00 \mathrm{wt} \%$ indicating fair to good source rocks. While the values for the Anambra Basin source rocks are between 2.46 and $66.43 \mathrm{wt} \%$ indicating good to excellent source rocks. This assumption is validated by the plot of
TOC (wt \%) versus S2 (Figure 5a). Also, the plot of S1 versus TOC (Figure 5b) according to [35], can be used to discriminate between indigenous (autochthonous) and nonindigenous (allochthonous) hydrocarbons. This relation points that all of the studied rock samples for the Sokoto and Anambra Basins source rocks were characterized by autochthonous hydrocarbons showing that oil in the studied source rocks originate from within the studied basins.

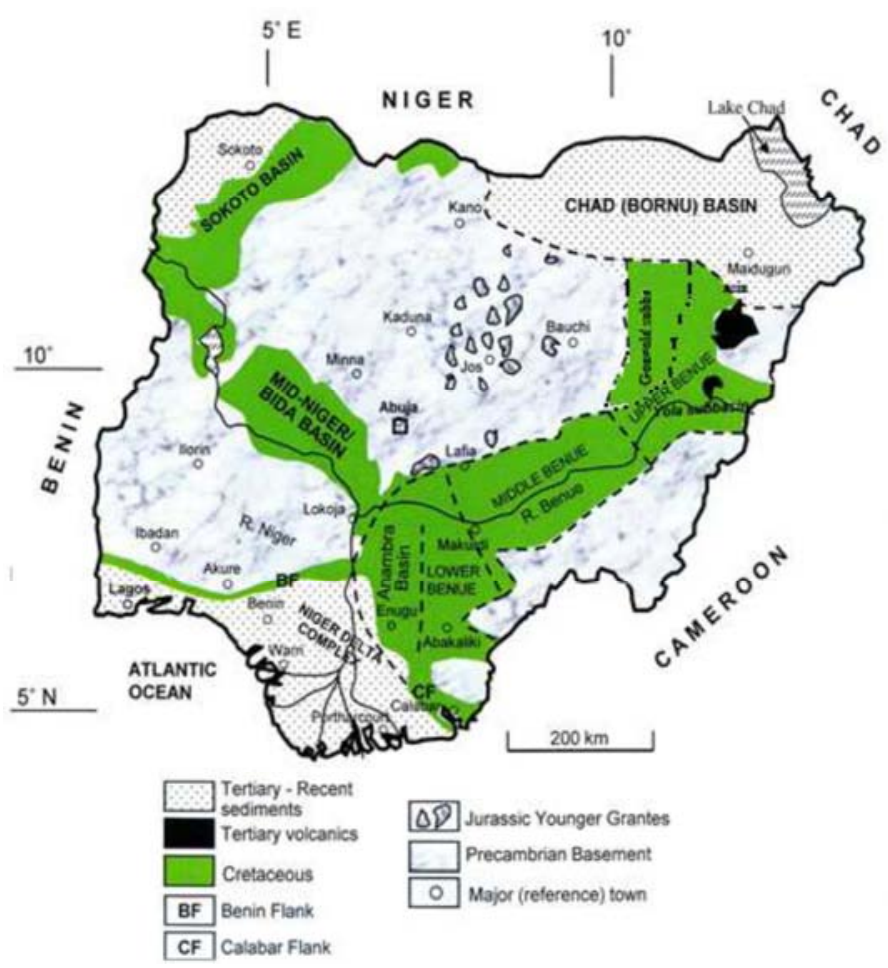

Figure 1. Generalized Geological sketch map of Nigeria showing the major geological components; Basement, Younger Granites, and Sedimentary Basins [8].

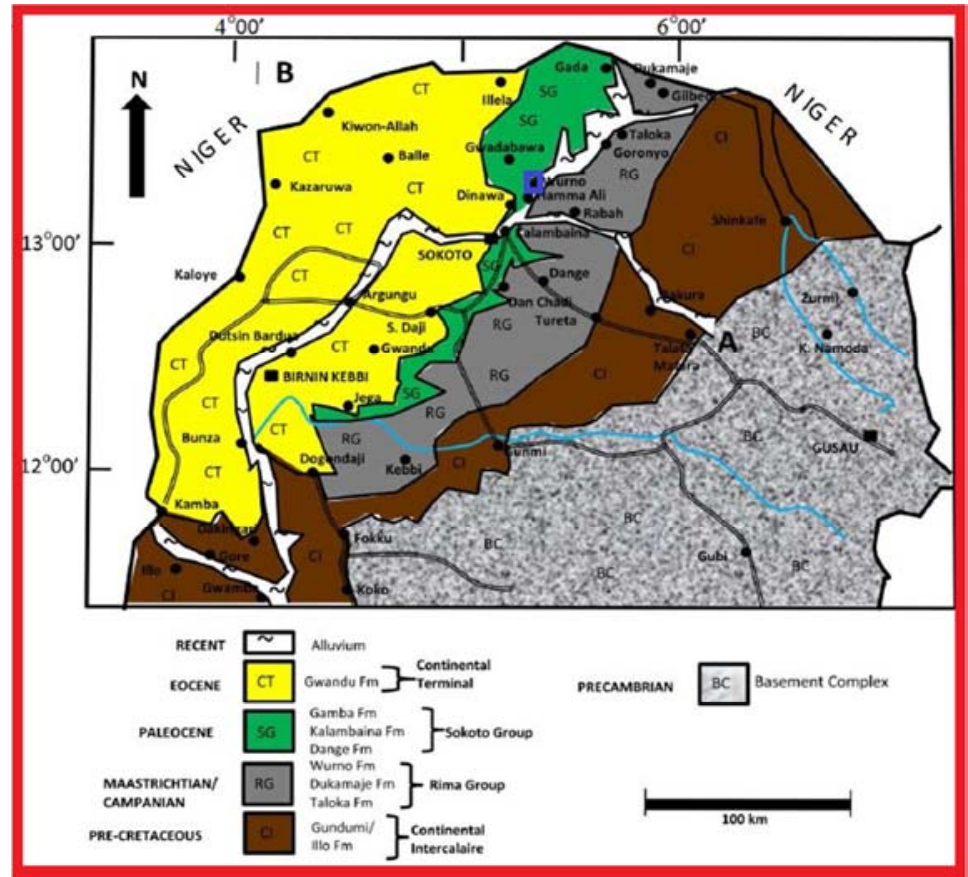

Figure 2. Generalized geological map of the Nigerian sector of the Iullemmeden Basin (Sokoto Basin) showing where samples of the Dukamaje shale were collected [3]. 


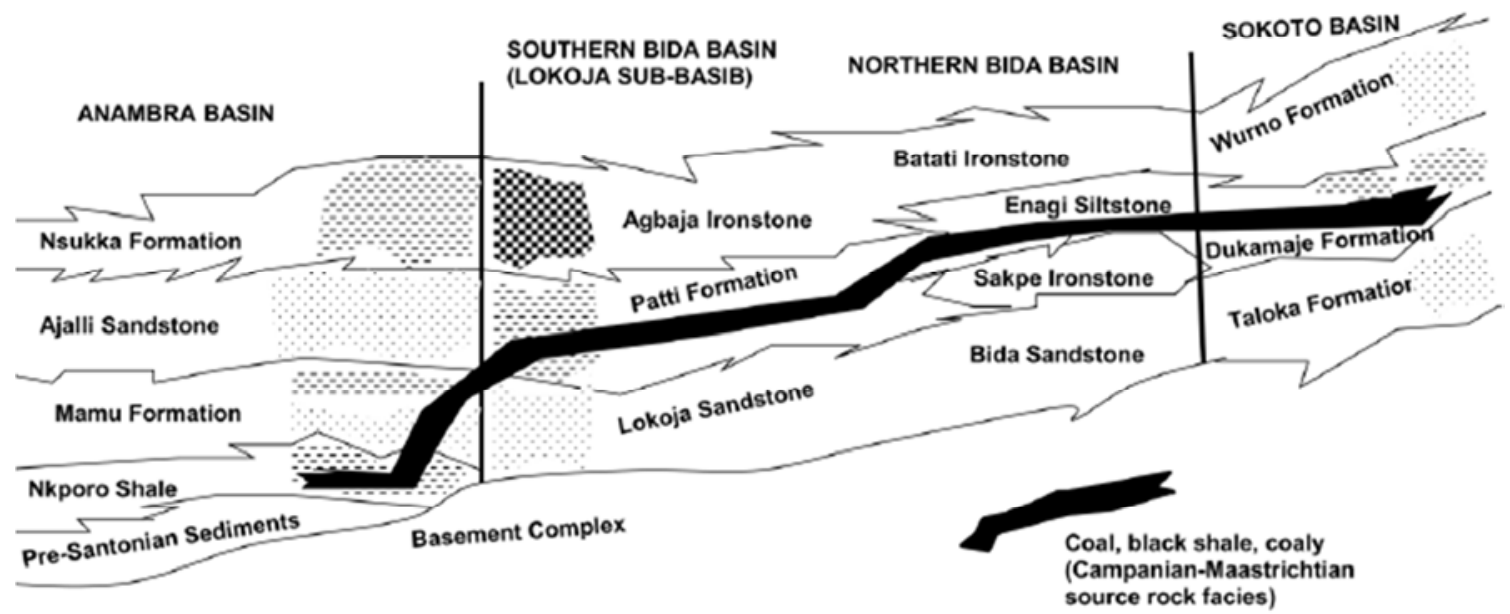

Figure 3. Stratigraphical cross-section and source rock development (coal, black shale, coaly) is a continuous linear belt from the Anambra Basin in the south through the Bida Basin in the middle to the Sokoto Basin in the northwest [1].

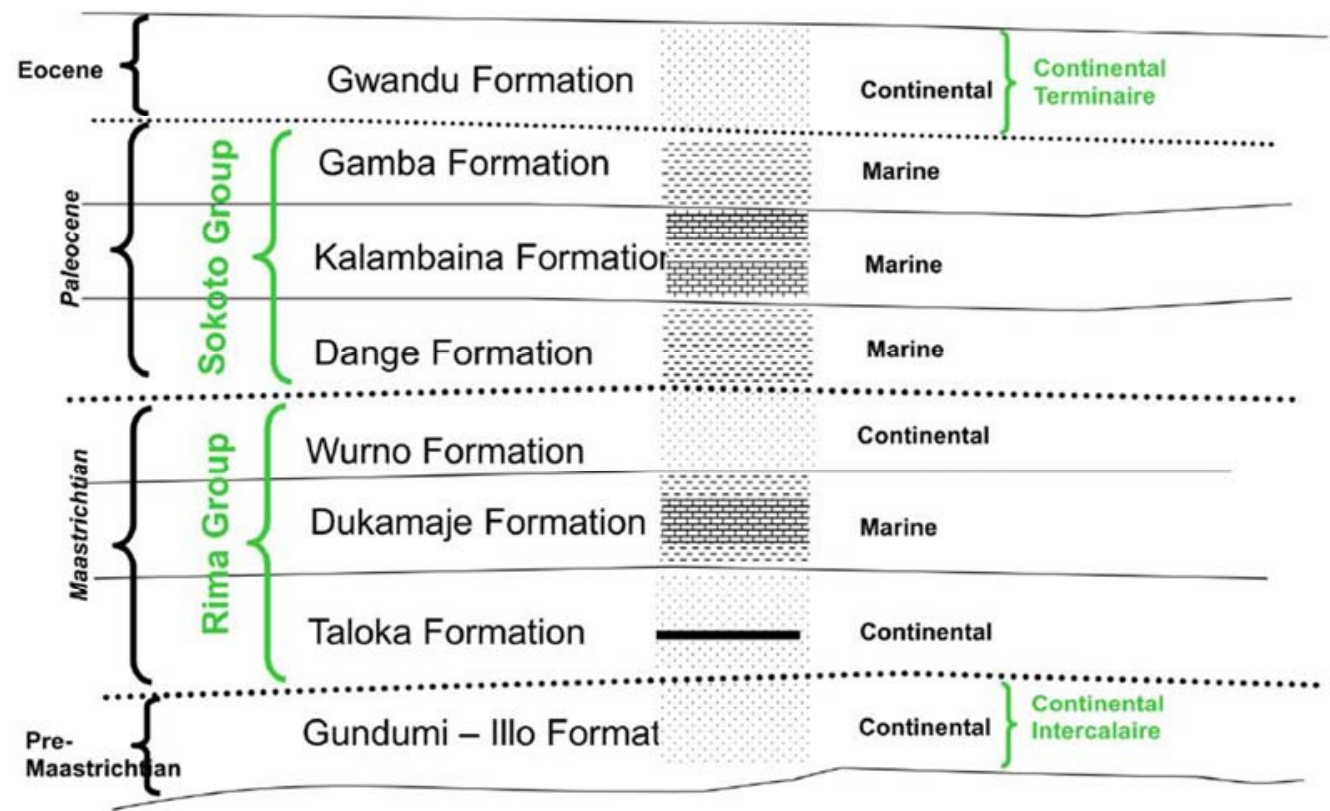

Figure 4. Stratigraphic successions in the Nigerian sector of the lullummeden Basin (Sokoto Basin) [8].

Table 1. Carbon determination (LECO) and Rock-Eval pyrolysis of the source rock samples from northwestern Sokoto and Anambra Basins, Nigeria.

\begin{tabular}{|c|c|c|c|c|c|c|c|c|c|c|}
\hline \multicolumn{11}{|c|}{ SAMPLE ID } \\
\hline & DKM1.8M & DKM2.5M & DKM3.0M & DKM3.2M & TLKL2 & TLKL4 & IBEA & ОКОВО & ESHAL1 & ONY \\
\hline TOC (wt \%) & 3.28 & 2.46 & 2.52 & 0.94 & 6.68 & 1.28 & 61.89 & 58.89 & 2.46 & 66.43 \\
\hline $\mathrm{S} 1$ (mg Hc/g rock) & 0.47 & 0.37 & 0.23 & 0.23 & 0.72 & 0.14 & 2.17 & 2.54 & 0.05 & 2.01 \\
\hline $\mathrm{S} 2$ (mg Hc/g rock) & 3.36 & 2.59 & 1.09 & 0.23 & 3.04 & 0.14 & 148.94 & 151.95 & 0.97 & 162.52 \\
\hline $\mathrm{S} 3(\mathrm{mg} \mathrm{CO} / \mathrm{g}$ rock $)$ & 0.73 & 0.5 & 1.35 & 0.38 & 5.12 & 0.5 & 6.28 & 10.89 & 0.9 & 2.46 \\
\hline $\mathrm{HI}$ (mg Hc/g TOC) & 102 & 105 & 43 & 24 & 46 & 11 & 241 & 258 & 39 & 245 \\
\hline $\mathrm{OI}(\mathrm{mg} \mathrm{CO} / \mathrm{g} \mathrm{TOC})$ & 22 & 20 & 54 & 40 & 77 & 39 & 10 & 18 & 37 & 4 \\
\hline PI & 0.12 & 0.13 & 0.17 & 0.5 & 0.19 & 0.5 & 0.01 & 0.02 & 0.05 & 0.01 \\
\hline $\operatorname{Tmax}\left({ }^{\circ} \mathrm{C}\right)$ & 418 & 416 & 407 & $* 413$ & 427 & $* 312$ & 421 & 421 & 410 & 430 \\
\hline
\end{tabular}

*PI Production Index S1/(S1+S2).

*HI Hydrogen Index (mg Hc/g TOC).

*OI Oxygen Index $(\mathrm{S} 3 \times 100) / \mathrm{TOC}(\mathrm{mg} \mathrm{CO} / \mathrm{g}$ TOC).

$* \operatorname{Tmax}\left({ }^{\circ} \mathrm{C}\right)$ Uncertain. 

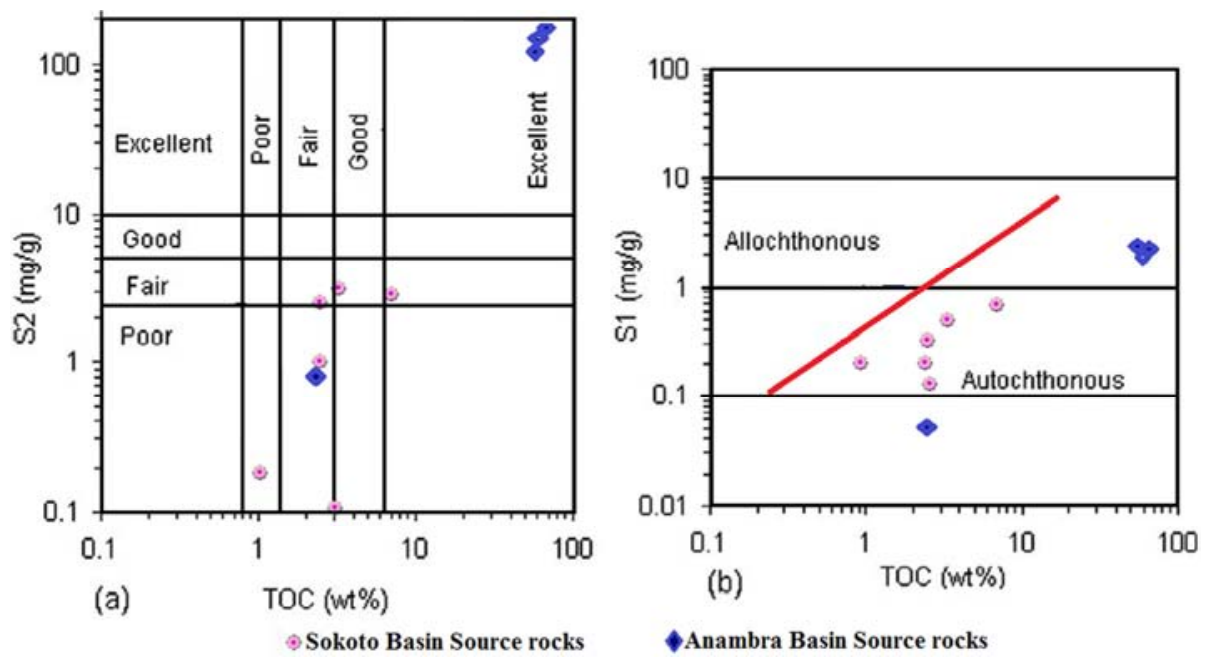

Figure 5. Quality and quantity of organic matter of Sokoto and Anambra Basins source rocks, Nigeria.

\subsubsection{Generating Potency}

The generation potency of a source rock is identified using the results of pyrolysis analysis. The genetic potency (GP) is the sum of the values S1 and S2. According to [36] source rocks with a GP $<2$, from 2 to 5 , from 5 to 10 and $>10$ are considered to have poor, fair, good, and very good generation potence, respectively. The relationship between $(\mathrm{S} 1+\mathrm{S} 2)$ and TOC [37]. (Figure 6a) shows that the Sokoto Basin (Dukamaje and Taloka shales) source rocks are considered as fair to good source potential except few samples that are considered as poor source potential while the Anambra Basin source rocks are considered as good to excellent source potential. On the other hand, the plot of TOC (wt \%) versus $\mathrm{HI} \mathrm{mg} / \mathrm{g}$ (Figure 6b) shows that the Sokoto and Anambra Basins source rocks are non-oil or gas source rocks.

\subsubsection{Genetic Organic Matter}

In petroleum prospectivity, the initial genetic type of organic matter of a particular source rock is essential for the prediction of oil and gas potential. Waples [32, 33, 37-41] used the hydrogen index values (HI) to differentiate between the types

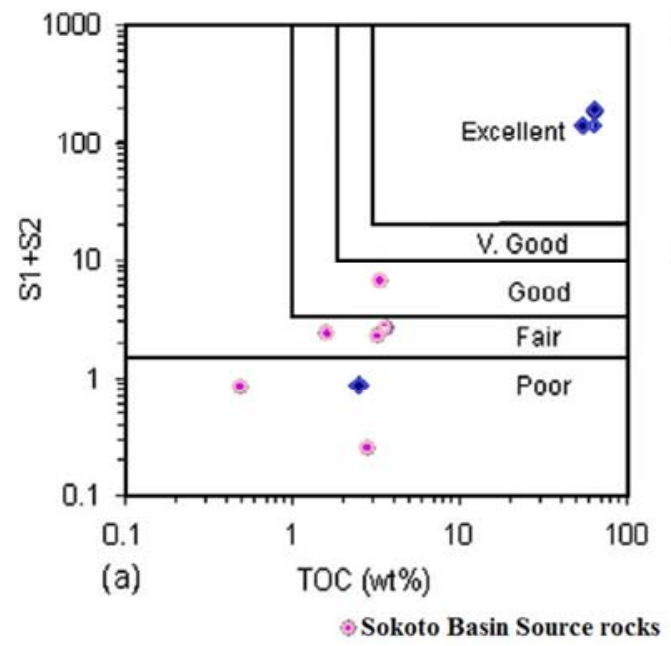

of organic matter. Hydrogen indices $<150 \mathrm{mg} / \mathrm{g}$ indicate a potential source for generating gas (mainly type III kerogen). Hydrogen indices between 150 and $300 \mathrm{mg} / \mathrm{g}$ contain more type III kerogen than type II and therefore are capable of generating mixed gas and oil but mainly gas. Kerogen with hydrogen indices $>300 \mathrm{mg} / \mathrm{g}$ contains a substantial amount of type II macerals and thus are considered to have good source potential for generating oil and minor gas. Kerogen with hydrogen indices $>600 \mathrm{mg} / \mathrm{g}$ usually consists of nearly type I or type II kerogen, they have excellent potential to generate oil.

In this study, we used $[42,43]$ kerogen type diagram which represents the plot TOC versus S2 (Figure 7a). This diagram shows that the Sokoto Basin source rocks are characterized by kerogen of type III, while the Anambra Basin source rocks are characterized by type II and type III. Based on pyrolysis data kerogen classification diagrams were constructed using the HI versus OI plot as opined by [44], popularly used to determine the kerogen type (Figure $7 \mathrm{~b}$ ). The results show that the analyzed Sokoto Basin samples are generally plotted under type III kerogen, while the analyzed Anambra Basin samples are plotted in kerogen of type III and type II.

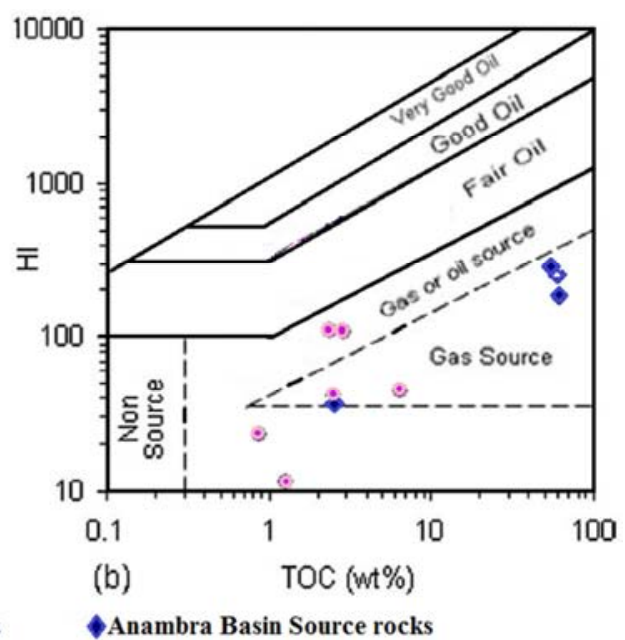

Figure 6. Generating potency of Sokoto Basin and Anambra Basins source rocks, Nigeria. 

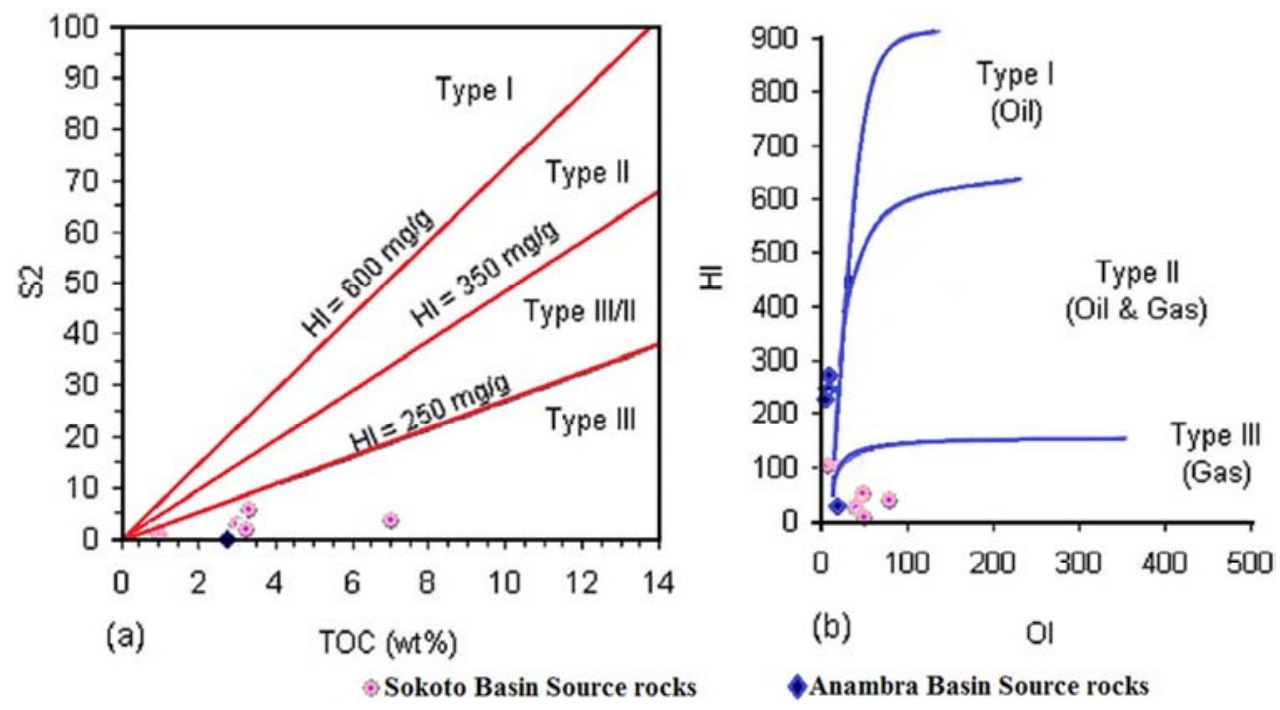

Figure 7. Genetic type of organic matter of Sokoto Basin and Anambra Basin source rocks, Nigeria.

\subsubsection{Thermal Maturation}

According to [26, 34, 45-49], the generation of petroleum from the organic matter during its burial history is a part of the overall process of thermal metamorphism of organic matter. The concentration and distribution of hydrocarbons inhibited in a particular source rely on both the type of the organic matter and its degree of thermal alteration [26, 29, $31,33,34,42]$. In the present study, the thermal maturity level of the source rocks has been unraveled by the examination of the geochemical parameters as Rock-Eval pyrolysis "Tmax", production index "PI" [36, 50]. Peters $[28,50,51,52]$ reported that oil generation from source rocks began at $T \max =435-465^{\circ} \mathrm{C}$. Production index "PI" between 0.2 and 0.4 , the organic matters are in immature stage when "Tmax" has a value less than $435^{\circ} \mathrm{C}$, and "PI"

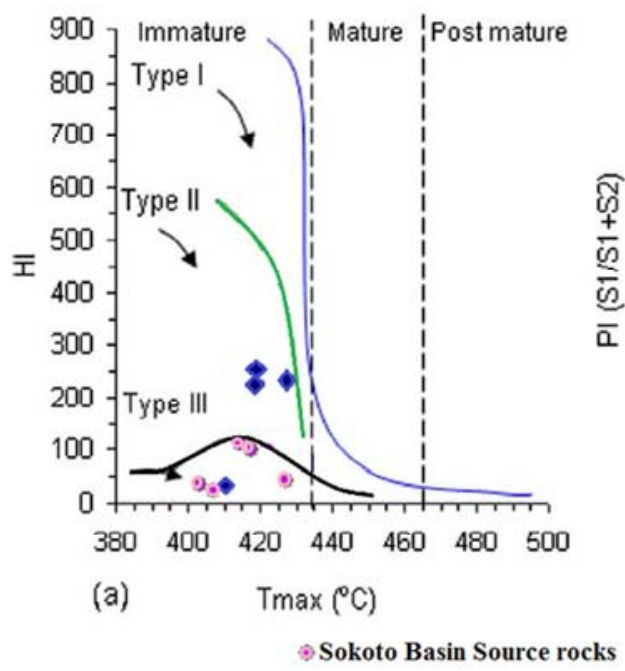

less than 0.2 and the gas generation from source rocks began at "Tmax" $470^{\circ} \mathrm{C}$, and production index "PI" more than 0.4 . Based on pyrolysis data kerogen classification diagrams were constructed using the HI versus Tmax plot as carried out by $[50,53]$ which is used to determine the kerogen type and maturity (Figure 8a). The results show that the analyzed Sokoto Basin samples are generally plotted in the immature zone of type III kerogen, while the analyzed Anambra Basin samples are plotted in the immature zone grading to marginally mature zone with kerogen of type III and type II. The plot of Tmax versus PI diagram [28, 37, 53] (Figure 8b) indicates that the Sokoto Basin source rocks are immature source rocks while, the Anambra Basin source rocks grade from immature to marginally mature.

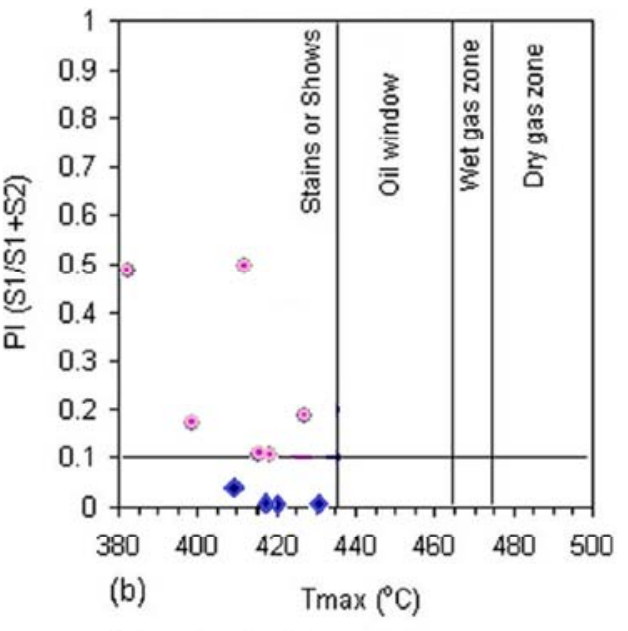

- Anambra Basin Source rocks

Figure 8. Thermal maturation of Sokoto and Anambra Basins source rocks, Nigeria.

\subsection{Statistical Methods}

In this study, the multivariate statistical analysis was employed. The multivariate statistical analysis is the construction of cluster analysis (hierarchical cluster analysis),
Factor analysis, K-independence sample T-tests, Pearson's correlation and linear regression.

\subsubsection{Cluster Analysis}

The set of 9 source parameters (Tmax, HI, OI, PI, S1, S2, 
$\mathrm{S} 3$, TOC, S1 + S2) were subjected to hierarchical cluster analysis using the standard method, which was proven to be the most reliable according to the up-to-date organic geochemical investigations [20, 32, 33, 34]. Based on the different $\mathrm{HI}$ values, the samples were distinguished into two main clusters. The first one (cluster I) of high HI values greater than $240 \mathrm{mg} / \mathrm{g}$ and the second (cluster II) of HI values lower than $240 \mathrm{mg} / \mathrm{g}$. However, the samples of cluster II of comparable HI values have showed variability in other parameters like TOC, S1, S2 and Tmax. The resulting dendrogram (Figure 9) showed two types of clusters which reflect two types of source rocks. Cluster I that represents
Anambra Basin source rock is found to be a fair source rock for oil generation with slightly higher thermal maturation and characterized by $\mathrm{HI}$ ranging from 241 to $258 \mathrm{mgHC} / \mathrm{g}$. TOC reflecting that these source rocks were characterized by kerogen type II and III. Cluster II mainly represents Dukamaje Formation with subordinate Taloka Formation and Enugu Shale which are characterized by HI ranging from 11 to $105 \mathrm{mgHC} / \mathrm{g}$. TOC reflecting kerogen type III. By applying K-means cluster analysis on the same set of source parameters, the results showed that all samples belong to cluster II except for three samples (IBEAGWA, OKOBO, ONYEAMA A) which belong to cluster I (Table 2).

Table 2. Average Linkage (Between Groups).

\begin{tabular}{|c|c|c|c|c|c|c|}
\hline \multicolumn{7}{|c|}{ Agglomeration Schedule } \\
\hline \multirow{2}{*}{ Stage } & \multicolumn{2}{|c|}{ Cluster Combined } & \multirow{2}{*}{ Coefficients } & \multicolumn{2}{|c|}{ Stage Cluster First Appears } & \multirow{2}{*}{ Next Stag } \\
\hline & Cluster 1 & Cluster 2 & & Cluster 1 & Cluster 2 & \\
\hline 1 & 1 & 2 & 18.328 & 0 & 0 & 7 \\
\hline 2 & 4 & 9 & 246.363 & 0 & 0 & 4 \\
\hline 3 & 7 & 10 & 352.649 & 0 & 0 & 5 \\
\hline 4 & 3 & 4 & 455.777 & 0 & 2 & 6 \\
\hline 5 & 7 & 8 & 539.191 & 3 & 0 & 9 \\
\hline 6 & 3 & 5 & 1688.193 & 4 & 0 & 7 \\
\hline 7 & 1 & 3 & 5656.849 & 1 & 6 & 8 \\
\hline 8 & 1 & 6 & 14472.914 & 7 & 0 & 9 \\
\hline 9 & 1 & 7 & 69498.513 & 8 & 5 & 0 \\
\hline
\end{tabular}

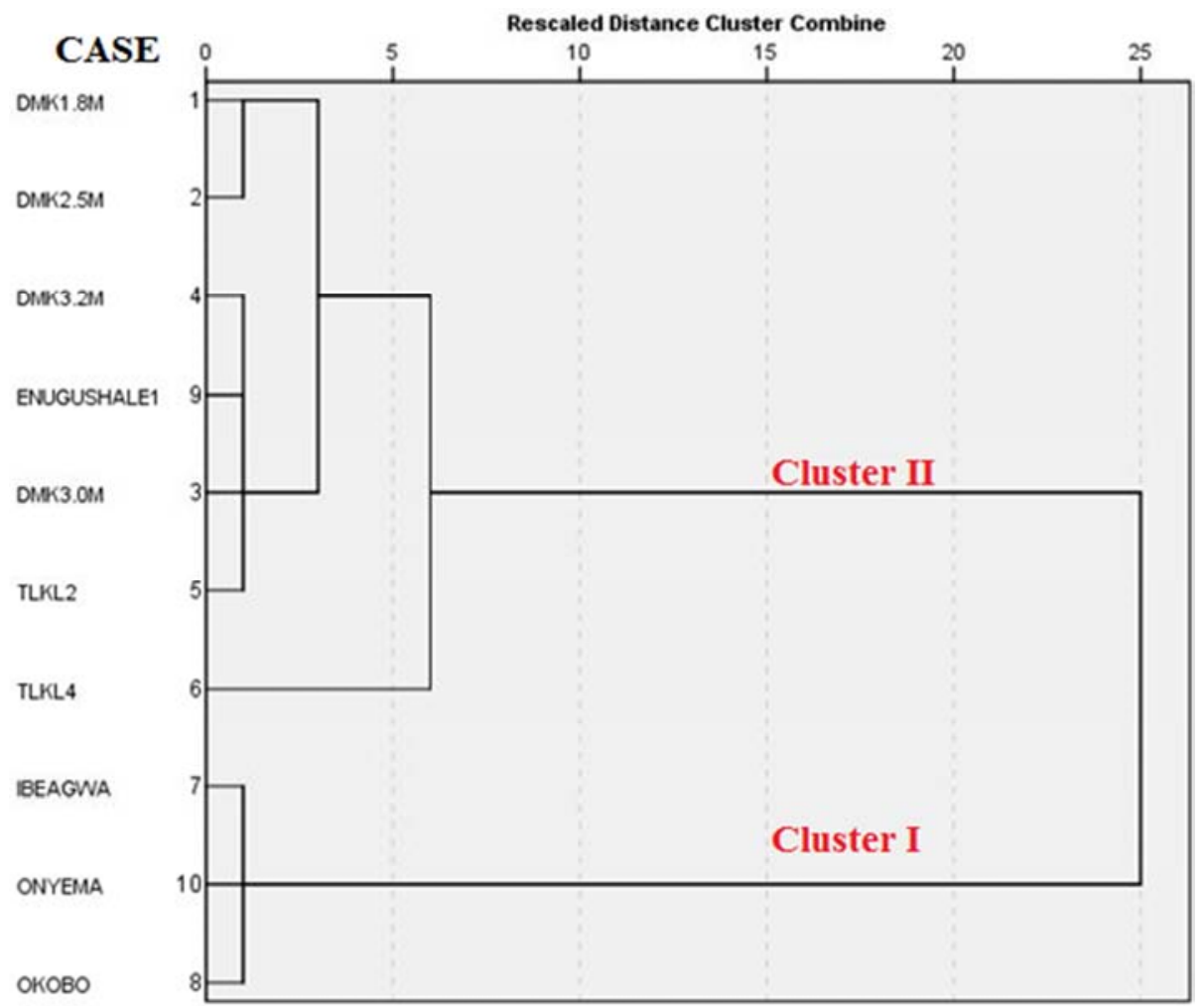

Figure 9. Hierarchical cluster analysis dendrogram using average linkage (between groups).

\subsubsection{Factor Analysis}

To get a more detailed classification of the source rock potential in the study area, a factor analysis of the source parameters was carried out using principle component analysis (Table 3 and Table 4). According to up-to-date organic geochemical investigations, this method has been shown to be the most convenient [50, 54]. Employing factor analysis on Rock-Eval pyrolysis variables shows three distinct factors affecting the evaluation of source rocks (Table 3). Factor 1 includes variables TOC, S1, S2 which ascertain the organic richness and hydrocarbon potency of 
source rocks and also HI which square up the type of organic matter that characterizes source rocks. Factor 2 and Factor 3 include variables PI and Tmax, which reflect the maturity of source rocks. In totality, factor analysis shows that evaluating the source rocks rely on determining hydrocarbon potency, organic richness, type of organic matter, and thermal maturity. Correlating the results derived by application of factor and cluster analyses methods; corroborate the existence of two distinct source rock types.

Table 3. Correlation matrix of the parameters in the studied source rocks.

\begin{tabular}{|c|c|c|c|c|c|c|c|c|c|}
\hline & & TOC & S1 & S2 & S3 & HI & OI & PI & TMAX \\
\hline \multirow{7}{*}{ Correlation } & TOC & 1.000 & .969 & .998 & .702 & .951 & -.655 & -.602 & .359 \\
\hline & $\mathrm{S} 1$ & .969 & 1.000 & .969 & .833 & .956 & -.575 & -.599 & .402 \\
\hline & $\mathrm{S} 2$ & .998 & .969 & 1.000 & .703 & .955 & -.676 & -.590 & .343 \\
\hline & $\mathrm{S} 3$ & .702 & .833 & .703 & 1.000 & .693 & -.152 & -.481 & .330 \\
\hline & HI & .951 & .956 & .955 & .693 & 1.000 & -.749 & -.713 & .467 \\
\hline & $\mathrm{OI}$ & -.655 & -.575 & -.676 & -.152 & -.749 & 1.000 & .444 & -.157 \\
\hline & PI & -.602 & -.599 & -.590 & -.481 & -.713 & .444 & 1.000 & -.667 \\
\hline \multirow{7}{*}{ Sig. (1-tailed) } & TOC & & .000 & .000 & .012 & .000 & .020 & .033 & .154 \\
\hline & $\mathrm{S} 1$ & .000 & & .000 & .001 & .000 & .041 & .034 & .125 \\
\hline & $\mathrm{S} 2$ & .000 & .000 & & .012 & .000 & .016 & .036 & .166 \\
\hline & S3 & .012 & .001 & .012 & & .013 & .338 & .080 & .176 \\
\hline & HI & .000 & .000 & .000 & .013 & & .006 & .010 & .087 \\
\hline & OI & .020 & .041 & .016 & .338 & .006 & & .099 & .332 \\
\hline & PI & .033 & .034 & .036 & .080 & .010 & .099 & & .018 \\
\hline
\end{tabular}

a. Determinant=6.994E-010.

Table 4. Total Variance of the parameters in the studied source rocks Explained.

\begin{tabular}{llllllll}
\hline \multirow{2}{*}{ Component } & \multicolumn{2}{l}{ Initial Eigen values } & \multicolumn{3}{l}{ Extraction Sums of Squared Loadings } & \multicolumn{2}{c}{ Rotation Sums of Squared Loadings $^{\text {a }}$} \\
\cline { 2 - 7 } & Total & \% of Variance & Cumulative \% & Total & \% of Variance & Cumulative \% & Total \\
\hline 1 & 5.616 & 70.201 & 70.201 & 5.616 & 70.201 & 70.201 & 4.984 \\
2 & 1.084 & 13.549 & 83.750 & 1.084 & 13.549 & 83.750 & 3.034 \\
3 & .865 & 10.807 & 94.558 & .865 & 10.807 & 94.558 & 2.647 \\
4 & .279 & 3.485 & 98.042 & & & & \\
5 & .139 & 1.735 & 99.778 & & & & \\
6 & .017 & .207 & 99.985 & & & & \\
7 & .001 & .012 & 99.997 & & & & \\
8 & .000 & .003 & 100.000 & & & & \\
\hline
\end{tabular}

\subsubsection{Pearson's Correlation Coefficient and Linear Regression Analyses}

According to the correlation coefficient can range from -1 to +1 , with -1 indicating a perfect negative correlation, +1 indicating a perfect positive correlation, and 0 indicating no correlation at all. (A variable correlated with it will always have a correlation coefficient of 1 ).

In this study, employing Pearson's correlation analysis shows a strong positive correlation between TOC and S1 and S2 (Table 5, Figure 10a and 10f) indicates the contribution of S1 and S2 from TOC. Furthermore, highly positive correlation between TOC and HI (Figure 10d), highly negative correlation with oxygen index (Figure 10b) and little to no correlation between TOC and Tmax (Figure 10e) and PI indicate that the maturity of source rocks is independent of the amount of organic matter [23]. Highly positive correlation between S1 and S2 (Figure 10f) and also between $\mathrm{S} 2$ and $\mathrm{HI}$ in addition to no correlation between Tmax and HI (Figure 10c) illustrate that the highest HI occurs at certain maturities and does not occur in stages of less maturity or over maturity. Highly negative reverse correlation between $\mathrm{HI}$ and OI was also shown (Figure 10b).

\section{Conclusions}

Integrated LECO, Rock-Eval pyrolysis and multivariate statistical analysis are examined to investigate the level and time of hydrocarbon generation and expulsion of shale and coal successions in northwestern Sokoto and Anambra Basins, they showed that the northwestern Sokoto Basin source rocks are poor to good source rocks with kerogen of type III and are capable of generating gas. The Anambra Basin source rocks are good to excellent source rocks with kerogen of type III and type II and are capable of generating oil and gas. Employing Hierarchical cluster analyses on the studied samples shows two clusters reflecting two types of source rocks. Cluster I are source rocks characterized by $\mathrm{HI}>240(\mathrm{mg} / \mathrm{g})$, TOC from 58.89 to166.43 wt \%, S1 from 2.01 to $2.54(\mathrm{mg} / \mathrm{g})$ and $\mathrm{S} 2$ from 148.94 to $162.52(\mathrm{mg} / \mathrm{g})$ indicating good to excellent source rocks with kerogen of type III and type II and are capable of generating oil and gas. Cluster II are source rocks characterized by $\mathrm{HI}<240(\mathrm{mg} / \mathrm{g})$, TOC from 0.94 to $6.68 \mathrm{wt} \%, \mathrm{~S} 1$ from 0.14 to $0.72(\mathrm{mg} / \mathrm{g})$ and S2 from 0.14 to $3.36(\mathrm{mg} / \mathrm{g})$ indicating poor to good source rocks with kerogen of type III and are capable of 
generating gas. Employing factor analysis on Rock-Eval pyrolysis variables indicates that there are three factors affecting the evaluation of source rocks. Factor 1 includes variables TOC, S1, S2 which determine the organic richness and hydrocarbon potentiality of source rocks and also $\mathrm{HI}$ which determine the type of organic matter that characterizes source rock. Factor 2 and Factor 3 include variables PI and Tmax which reflect the maturity of source rocks. Pearson's correlation analysis shows a strong positive correlation between TOC and S1 and S2 indicates the contribution of S1 and S2 from TOC. Furthermore, highly positive correlation between TOC and HI, highly negative correlation with oxygen index and no correlation between TOC and Tmax and PI indicate that the maturity of source rocks is independent of the amount of organic matter. Highly positive correlation between $\mathrm{S} 1$ and $\mathrm{S} 2$ and also between $\mathrm{S} 2$ and $\mathrm{HI}$ in addition to, no correlation between Tmax and HI illustrate that the highest HI occurs at certain maturities and doesn't occur in stages of less maturity or over maturity. Highly negative reverse correlation between $\mathrm{HI}$ and OI was also shown.

Table 5. Linear regression coefficients of the parameters in the studied source rocks.

\begin{tabular}{|c|c|c|c|c|c|c|}
\hline \multirow{2}{*}{\multicolumn{2}{|c|}{ Model }} & \multicolumn{2}{|c|}{ Unstandardized Coefficients } & \multirow{2}{*}{$\begin{array}{l}\text { Standardized Coefficients } \\
\text { Beta }\end{array}$} & \multirow{2}{*}{$\mathbf{T}$} & \multirow{2}{*}{ Sig. } \\
\hline & & B & Std. Error & & & \\
\hline \multirow{8}{*}{1} & (Constant) & 12.497 & 11.205 & & 1.115 & .381 \\
\hline & S1 & 21.343 & 12.898 & .706 & 1.655 & .240 \\
\hline & $\mathrm{S} 2$ & .298 & .065 & .763 & 4.624 & .044 \\
\hline & $\mathrm{S} 3$ & -1.657 & .721 & -.200 & -2.298 & .148 \\
\hline & $\mathrm{HI}$ & -.115 & .094 & -.394 & -1.223 & .346 \\
\hline & OI & -.015 & .110 & -.011 & -.136 & .904 \\
\hline & PI & -17.000 & 9.769 & -.109 & -1.740 & .224 \\
\hline & TMAX & -.010 & .021 & -.012 & -.464 & .688 \\
\hline
\end{tabular}

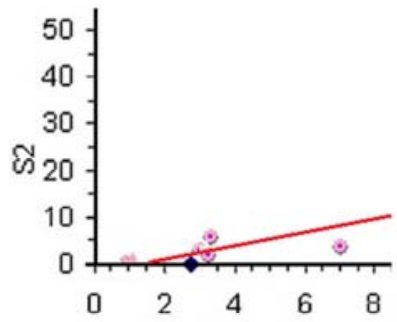

(a) TOC (wt\%)

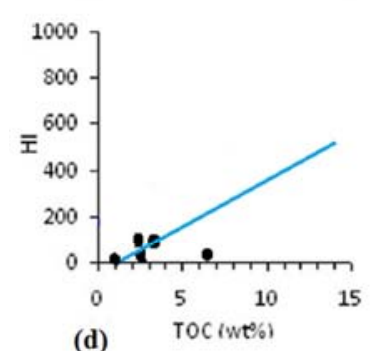

(d)

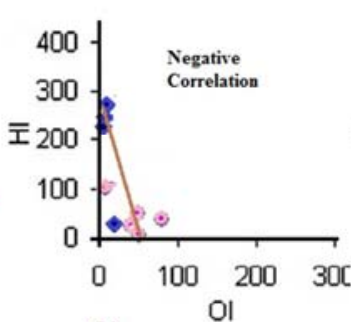

(b)
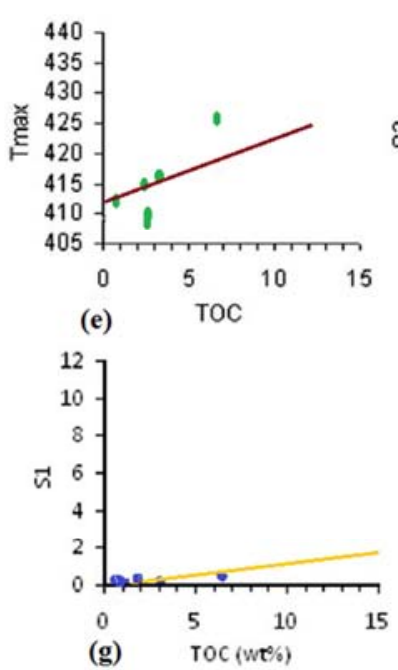
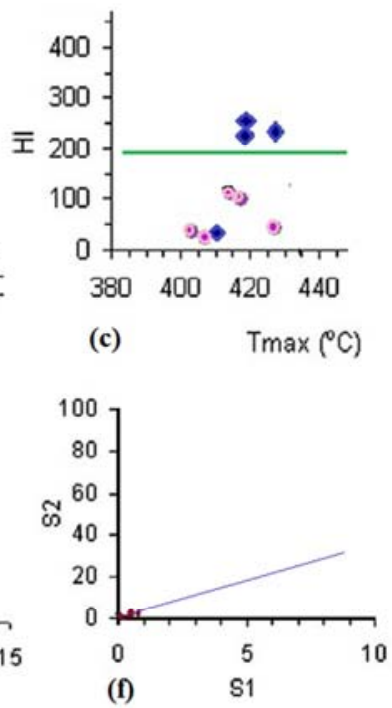

(f) $\quad \mathrm{s} 1$

Figure 10. Pearson's correlation coefficient of the studied samples.

\section{Acknowledgements}

Great acknowledgments goes to the Nigerian National Petroleum Corporation through the office of the NNPC Chair in Basinal Studies, Ibrahim Badamasi Babangida University, Lapai, Nigeria and the Sokoto State Government for supporting different aspects of the Sokoto Basin hydrocarbon prospectivity evaluation.

\section{References}

[1] Obaje, N. G., Aduku, M. and Yusuf, I. (2013). The Sokoto Basin of Northwestern Nigeria: A preliminary assessment of the hydrocarbon prospectivity. Petroleum Technology Development Journal, 3 (2): 71-86. 
[2] Obaje, N. G., Umar, U. M., Aweda, A. K. and Ozoji, T. M. (2020a). Nigerian Cretaceous Coal Deposits and their Petroleum Source Rock Characteristics. International Journal of Petroleum and Gas Exploration Management, 4 (1): 1-14.

[3] Obaje, N. G, Faruq, U. Z., Bomai, A., Moses, S. D., Ali, M., Adamu, S., Essien, A., Lamorde, U., Umar, U. M., Ozoji, T., Okonkwo, P., Adamu, L. and Idris-Nda, A (2020b). A Shot Note on the Petroleum Potential of the Sokoto Basin in Northwestern Nigeria: Petroleum Science and Engineering, 4 (1): 34-38.

[4] Behar, F., Beaumont, V. and Penteado, H. L. D. B. (2001). Rock-Eval technology: performances and developments: Oil Gas Sci. Technol. 56: 111-134.

[5] Kogbe, C. A. (1979). Geology of the South-eastern (Sokoto) Sector of the Iullemmeden Basin. Dept. of Geology: Ahmadu Bello University Zaria Bulletin, 32: 1-142.

[6] Kogbe, C. A (1981). Cretaceous and Tertiary of the Iullemmeden Basin of Nigeria (West Africa): Cretaceous Research, 2: 129-186.

[7] Obaje, N. G. (1987). Foraminiferal biostratigraphy and paleoenvironment of the Sokoto Basin of NW Nigeria. M. Sc Thesis, Ahmadu Bello University, Zaria, 76pp.

[8] Obaje, N. G. (2009). Geology and Mineral Resources of Nigeria. Springer, Heildelberg, 221pp.

[9] Murat, R. C. (1972). Stratigraphy and palaeogeography of the Cretaceous and Lower Tertiary in southern Nigeria. In: Dessauvagie, T. F. J., Whiteman, A. J., (eds). African Geology. Nigeria: University of Ibadan Press, 251-266.

[10] Mode. A. W. and Onuoha, K. M. (2001). Organic matter Evaluation of the Nkporo Shale, Anambra Basin, from wireline logs": Global Journal of Applied Sci., (7): 103107.

[11] Adamu, L. M., Rufai A., Odoma, A. N. and Alege, T. S. (2017). Sedimentology and Depositional Environment of the Mid-Maastritchtian Ajali Sandstone in Idah and Environs, Northern Anambra Basin, Northcentral Nigeria. Journal of Applied Geology and Geophysics, 6 (1): 38-51

[12] Nwajide C. S. and Reijers, T. J. A. (1996). Geology of the Southern Anambra Basin. In: Reijers, T. J. A. (Ed.), Selected Chapters on Geology: SPDC, Warri, 133-148.

[13] Nwajide, C. S. (2014). Geology of Nigerian Sedimentary Basins: CSS Publishers, 645pp.

[14] Adamu, L. M., Rufai A. and Alege, T. S. (2018). Sedimentology and Depositional Environment of the Maastritchtian Mamu Formation, Northern Anambra Basin, Nigeria. Advances in Applied Science Research, 9 (2): 53-68.

[15] Obaje, N. G., Ulu, O. K. and Petters, S. W. (1999). Biostratigraphic and geochemical controls of hydrocarbon prospects in the Benue Trough and the Anambra Basin, Nigeria. Nigerian Association of Petroleum Explorationists Bulletin, 14: 18-54.

[16] Adebayo, O. F., Akinyemi, S. A. and Ojo, A. O. (2015). Palaeoenvironmental studies of Odagbo coal mine sequence, Northern Anambra Basin, Nigeria: insight from palynomorph and geochemical analyses. Int J Curr Res, 7 (9): 20274 20286.
[17] Edegbai, A. J., Schwarka, L. and Oboh-Ikuenobe, F. E. (2019). Campano-Maastrichtian paleoenvironment, paleotectonics and sediment provenance of western Anambra Basin, Nigeria: Multi-proxy evidences from the Mamu Formation. Journal of African Earth Sciences, 156: 203-239.

[18] Dim, C. I. P., Onuoha, K. M., Okwara, I. C., Okonkwo, I. A. and Ibemesi, P. O. (2019). Facies analysis and depositional environment of the Campano -Maastrichtian coal-bearing Mamu Formation in the Anambra Basin, Nigeria. Journal of African Earth Sciences 152: 69-83.

[19] Zhang, T. P., Zhang, Y. C. and Cai, K. Z. (2007). SPSS Statistic Modeling and Analytic Procedure: Kings Information Co., Ltd., Taipei, 674pp.

[20] El-Nady, M. M. and Lotfy, N. M. (2016). Multivariate geochemical and statistical methods applied to assessment of organic matter potentiality and its correlation with hydrocarbon maturity parameters (Case study: Safir-1x well, North Western Desert Egypt): Egyptian Journal of Petroleum, http://dx.doi.org/10.1016/j.ejpe.2015.12.001.

[21] Goloboc`anin, D. D., S`krbic', B. D. and Miljevic', N. R. (2004). Principal component analysis for soil contamination with PAHs: Chemometrics Intelligent Lab. Sys., 72: 219-223.

[22] Joreskog, K. G., Klovan, J. E. and Reyment, R. A. (1978). Geological factor analysis: Journal of Geology, 86 (4): 435438 .

[23] Reimann, C., Filzmoser, P. and Garrett, R. G. (2002). Factor analysis applied to regional geochemical data: problems and possibilities: Appl. Geochem. 17: 185-206.

[24] Solevic, T., Stojanovic, K., Jovancicevic, B., Mandic, G. and Schwarzbauer, J. (2008). Origin of oils in the Velebit oil-gas field, SE Pannonian basin, Serbia-Source rocks characterization based on biological marker distributions: Org. Geochem., 39: 118-134.

[25] Golovko, A. and Pevneva, A. (2013). 21st International Meeting on Organic Geochemistry. Krakow, 73pp.

[26] Tissot, B. P. and Welte, D. H. (1984). Petroleum Formation and Occurrence, second ed.: Springer, New York, 699pp.

[27] Peters, K. E. and Cassa, M. R. (1994). Applied source rock geochemistry. in: L. B. Magoon, W. G. Dow, (Eds.), The Petroleum System -From Source to Trap: AAPG Memoir, 60: 93-120.

[28] Peters, K. E. (1986). Guidelines for evaluating petroleum source using programmed pyrolysis: AAPG Bull. 70: 318-329.

[29] Nton, M. E. and Awarun, A. O. (2011). Organic geochemical characterization and hydrocarbon potential of subsurface sediments from Anambra Basin, Southeastern Nigeria: Org. Geochem.: 162: 23-42.

[30] Atta-Peters, D. and Garrey, P. (2014). Source rock evaluation and hydrocarbon potential in the Tano Basin, Southwest Ghana, West Africa. International Journal of Oil, Gas and Coal Engineering: 2 (5): 66-77.

[31] Adilbi, A. N. F., Kolo, K., Muhammed, N. R., Yasin, S. R., Mamaseni, W. J. and Akram, R. (2019). Source rock evaluation of shale intervals of the Kurra Chine Formation, Kurdistan Region Iraq: An organic geochemical and basin modeling approach: Egyptian Journal of petroleum, Elsevier: 28: $315-321$. 
[32] El Nady, M. M., Ramadan, F. S., Hammad, M. M., Mousa, D. A. and Lotfy, N. M. (2018). Hydrocarbon potentiality and thermal maturity of the Cretaceous rocks in Al Baraka oil field, Komombo Basin, south Egypt: Egyptian Journal of petroleum, Elsevier: 27: 1131-1143.

[33] Koji, U. T., Takeshi, N., Yuichiro, S., Sumito, M., Takayuki, S. and Yasuaki, H. (2020). Hydrocarbon generation potential and thermal maturity of coal and coaly mudstones from the Eocene Urahoro Group in the Kushiro coalfield, eastern Hokkaido, Japan: International Journal of Coal Geology, Elsevier: 217: 1-10.

[34] Xiangxin, K., Zaixing, J., Chao, H. and Ruifeng, Z. (2020). Organic matter enrichment and hydrocaborn accumulation models of the marlstone in the Shulu Sag, Bohai Bay Basin, Northern China: International Journal of Coal Geology, Elsevier: 217: 1-15.

[35] Ghori, K. R. and Haines, P. W. (2007). Paleozoic petroleum systems of the canning basin, Western Australia: Search and Discovery Article \# 10120.

[36] Hunt, J. M. (1996). Petroleum Geochemistry and Geology, second ed., W. H. Freeman and Company.

[37] Waples, D. W. (1985). Geochemistry in Petroleum Exploration: Boston, inter. Human Resources and Develop. Co., 232pp.

[38] El Nady, M. M., Ramadan, F. S., Eysa, E. A. and Said, N. M. (2016). The potentiality of hydrocarbon generation of the Jurassic source rocks in Salam-3x well, North Western Desert, Egypt: Egyptian Journal of Petroleum, Elsevier: 25: 97-105.

[39] Petersen, H. I. (2006). The petroleum generation potential and effective oil window of humic coals related to coal composition and age: Int. J. Coal Geol: 67: 221-248.

[40] Petersen, H. I., Lindstrom, S., Nytoft, H. P. and Rosenberg, P. (2009). Composition, peat forming vegetation and kerogen paraffinicity of Cenozoic coals: relationship to variations in the petroleum generation potential (Hydrogen Index): Int. J. Coal Geol.: 78: 119-134.

[41] Karayiğit, A., Littke, R., Querol, X., Jones, T., Oskay, R. G. and Christanis, K. (2017). The Miocene coal seams in the Soma Basin (W. Turkey): Insights from coal petrography, mineralogy and geochemistry: Int. J. Coal Geol.: 173: 110128.

[42] Longford, F. F. and Blanc-Valleron, M. M. (1990). Interpreting Rock-Eval Pyrolysis Data using Graphs of pyrolizable Hydrocarbons vs. Total Organic Carbon. AAPG Bulletin, 74 (6): 799-804.

[43] Bordenove, M. L., Espitalie, J., Leplat, P., Oudin, J. L. and Vandenbrouke, M. (1993). Screening techniques for source rock evaluation. in: Bardenove (ed.): Appl. Petrol. Geochem, Paris Eds. Technip. 217-278.

[44] Van Krevelen, D. W. (1961). Coal: Typology-ChemistryPhysics Constitution: Elsevier Science, Amsterdam, 514pp.

[45] Lai, H., Li, M., Liu, J., Mao, F., Xiao, H., He, W. and Yang, L. (2018). Organic geochemical characteristics and depositional models of Upper Cretaceous marine source rocks in the Termit Basin, Niger. Palaeogeogr. Palaeoclimatol: Palaeoecol: 495: 292-308.

[46] Zhao, X., Li, Q., Jiang, Z., Zhang, R. and Li, H. (2014). Organic geochemistry and reservoir characterization of the organic matter-rich calcilutite in the Shulu Sag, Bohai Bay Basin, North China: Mar. Pet. Geol.: 51, 239-255.

[47] Zou, C., Zhu, R., Chen, Z., Ogg, J. G., Wu, S., Dong, D., Qiu, Z., Wang, Y., Wang, L., Lin, S., Cui, J., Su, L. and Yang, Z. (2019). Organic-matter-rich shales of China: Earth Sci. Rev.: 189: $51-78$

[48] Han, Y., Horsfield, B. and Curry, D. J. (2017). Control of facies, maturation and primary migration on biomarkers in the Barnett Shale sequence in the Marathon 1 Mesquite well, Texas: Mar. Pet. Geol.: 85: 106-116.

[49] Hakimi, M. H., Abdullah, W. H., Alqudah, M., Makeen, Y. M. and Mustapha, K. A. (2016). Organic geochemical and petrographic characteristics of the oil shales in the Lajjun area, Central Jordan: origin of organic matter input and preservation conditions: Fuel: 181: 34-45.

[50] Espitalie, J., Deroo, G. and Marquis, F. (1985). La pyrolyse Rock-Eval et ses applications: Revue de I'Institut Francais du petrole, 40: 563-579 and 755-784.

[51] El Nady, M. M. and Hammad, M. M. (2015). Organic richness, kerogen types and maturity in the shales of the Dakhla and Duwi formations in Abu Tartur area Western Desert Egypt: Implication of Rock-Eval pyrolysis: Egyptian Journal of Petroleum, Elsevier: 24: 423-428.

[52] Pitman, J. K. and Rowan, E. (2012). Temperature and Petroleum Generation History of the Wilcox Formation, U.S. Geological survey Open-File Report, Louisiana.

[53] Nunn, J. A. (2012). Burial and thermal history of the Haynesville shale: implications for overpressure, gas generation, and natural hydrofracture: GCAGS J.: 1: 81-96.

[54] Wilhelms, A., Teln, S. N., Steen, A. and Augustson, J. (1998). A quantitative study of aromatic hydrocarbons in a natural maturity shale sequence- the 3-methylphenanthrene/retene ratio, a pragmatic maturity parameter: Org. Geochem. 29: 97-105. 